\title{
POST-TRANSPLANT LYMPHOPROLIFERATIVE DISORDER
}

\author{
Lucie Kalinova*, Jarmila Indrakova, Petr Bachleda
}

\author{
Department of Surgery II, University Hospital, I. P. Pavlova 6, 775 20, Olomouc, Czech Republic \\ e-mail: lucie.kalinova@email.cz
}

Received: August 17, 2009; Accepted: October 16, 2009

Key words: Posttransplant lymphoproliferative disorder/Lymphoproliferation/Immunosuppression

Backround: Posttransplant lymphoproliferative disorder (PTLD) is increasingly recognized as a serious complication of solid organ transplantation in both children and adults. Factors associated with increased risk of PTLD include mismatch of recipient and donor EBV serologic status (seronegative recipient with seropositive donor), and intensive drug-induced immunosuppression.

Methods and results: We searched MEDLINE for articles published since 1970 to January 2009. Search terms included posttransplant lymphoproliferative disorder, immunosuppression, posttransplant malignancy, treatment, antiviral agents, rituximab, interferon alpha, chemotherapy, radiation, surgery. Studies in English of adult and pediatric populations after solid organ transplantation were selected and analyzed.

Conclusion: Screening of patients at risk and balancing the intensity of immunosuppression against the risk of allograft rejection could reduce the risk of developing PTLD. In patients who develop PTLD, the severity and extent of disease should be examined and an individualized treatment plan including immunosuppression reduction and other agents should accordingly be chosen.

\section{INTRODUCTION}

Posttransplant lymphoproliferative disorder (PTLD) is a heterogenous group of lesions occurring after solid organ and bone marrow transplantation ${ }^{1-6}$. PTLD is one of the most serious complications of chronic immunosuppression. The majority of malignant lymphoproliferative disorders occurring after solid organ transplantation are of B-cell origin but they it may also originate from T-cells ${ }^{7-12}$, and extremely rarely from natural killer (NK) cells ${ }^{9}$. B-cell proliferation is predominantly induced by infection with Epstein-Barr virus (EBV) but EBV-negative disease has also been reported ${ }^{13}$. Most PTLD cells found in patients with solid organ allografts are of host origin ${ }^{14}$.

The histologic spectrum of PTLD ranges from hyperplastic lesions, which sometimes resemble infectious mononucleosis, to atypical lymphoid lesions, to lymphomas. The vast majority of lymphomatous PTLD are nonHodgkin lymphoma (NHL) ${ }^{15}$.

The overall incidence of post-transplant lymphoproliferative disease varies from 1 to 20 percent depending on the type of organ transplanted, patient age, EpsteinBarr virus (EBV) serostatus of recipient and donor and, aggressive immunosuppression ${ }^{16}$. PTLD can develop any time after transplantation (1 month to many years), although most cases are observed in first posttransplant year. PTLD is an increasingly significant cause of morbidity and mortality. The cited mortality of solid organ transplant recipients with PTLD is 60 percent $^{8,17}$.

The clinical presentation varies with constitutional symptoms of fever, malaise, an infectious mononucleosislike syndrome, palpable lymphadenopathy and symptoms related to organ dysfunction. Histopathological evidence of lymphoproliferation on tissue biopsy is necessary to confirm the diagnosis ${ }^{18,19}$.

Survival rates depend mainly on age and extent of disease at the time of diagnosis. Pediatric patients and patients with localized disease have the best prognosis. The most aggressive are monomorphic leasions.

Treatment ranges from reduction or withdrawal of immunosuppression to chemotherapy and radiation treatment. Therapeutic approaches also include antiviral and cellular therapy.

Prior to 1981, all posttransplant lymphoproliferative disease entities were uniformly referred to as immunoblastic sarcomas. In 1981 Hanto et al. ${ }^{20}$ published their findings on a renal transplant population at the University of Minnesota of a relationship between the Epstein-Barr virus and posttransplant lymphoproliferations. At the same time Frizzera et al. ${ }^{21}$ studied tumors from a group of renal transplant recipients and observed several forms of lymphoproliferation that had not been described before. Given the heterogeneity in tumor cell size and shape he called them "polymorphic". Further investigation showed that tumors are composed of B-lymphocytes. Frizzera et al. ${ }^{21}$ created a classification system which differentiated nonspecific reactive hyperplasia from polymorphic diffuse B cell hyperplasia and polymorphic diffuse B cell lymphoma and from immunoblastic sarcoma. Later Nalesnik et al. ${ }^{3}$ investigated a transplant population at the University of Pittsburg and in 1988 they set up the new classification system. As they did not discern any difference in the clinical presentation of the two types of polymorphic lesions they included them both under the term, polymorphic PTLD. To distinguish the group of lesions which resemble typical non- Hodgkin's lymphomas 
in occurrence and aggressive behavior they introduced the term monomorphic PTLD ${ }^{22}$. In 1989 Locker and Nalesnik described several categories of PTLD based on combined pathologic, immunohistopathologic and molecular characteristics ${ }^{23}$. In 1995 the classification system of Knowles et al. ${ }^{25}$ was established. There were three categories of PTLD - the first consisted of reactive hyperplasia of plasma cells, the second comprised lesions of polymorphic hyperplasia and polymorphic lymphoma, both of which were monoclonal and lacked oncogene and tumor suppressor gene alterations. The third category was formed by true lymphomas and hematopoietic neoplasms which were monoclonal and contained proto-oncogenes and/or tumor suppressor gene alterations ${ }^{24}$. The Society for Hematopathology Workshop Classification in 1997 determined several distinct categories of PTLD. These included early lesions, polymorphic PTLDs, monomorphic PTLDs (B and T cell lymphomas), plasmacytoma-like lesions, and T cell-rich large B cell lymphoma/Hodgkin's disease-like lesions ${ }^{25}$. In 2001, Harris, Swerdlow, Frizzera and Knowles reviewed the classification system for the 2001 World Health Organization Classifications of Tumors $^{26}$. Since then the WHO Classification has remained in widest use, with the last updating in 2008.

Table 1. Posttransplant lymphoproliferative disorder (PTLD) - WHO Classification 2008.

\begin{tabular}{|l|l|}
\hline M-9971/1 & $\begin{array}{l}\text { Early lesions } \\
\text { Plasmacytic hyperplasia } \\
\text { Infectious mononucleosis-like PTLD }\end{array}$ \\
\hline M-9971/3 & Polymorphic PTLD \\
\hline & $\begin{array}{l}\text { Monomorphic PTLD (B and T/NK cell } \\
\text { types) }\end{array}$ \\
\hline & Classical Hodgkin lymphoma type PTLD \\
\hline
\end{tabular}

\section{PATHOPHYSIOLOGY}

Most cases of PTLD are associated with EBV infection from B-lymphocytes, which in the setting of immunosuppression, can induce a transformation to a lymphoproliferative disorder. EBV is a herpes virus that is found in the oropharyngeal tissue of nearly 95 percent of the adult population. A primary infection with EBV is typically acquired during childhood through infected saliva, via breast milk, or as an infectious mononucleosis. The majority of primary EBV infections are subclinical while in adults the clinical syndrome of infectious mononucleosis may be present. It has been estimated that approximately 90 percent of the global population harbor EBV by the age of $40^{27}$. Structurally, the EBV virus is composed of the EBV genome and nuclear capsid surrounded by a glycoprotein envelope. The CD21 molecule on the surface of the $\mathrm{B}$ cell is the target receptor of the EBV glycoprotein envelope. During primary infection, EBV incorporates into
B-lymphocytes which transform and immortalize. Once a person is infected with EBV, the virus persists for life as a result of latency. Latent EBV infection is associated with a number of different malignancies, including PTLD, HIVassociated lymphomas, endemic Burkitt's lymphoma, and a subset of Hodgkin's lymphoma. In PTLD, EBV-latent membrane protein 1 (LMP1) has been implicated in the transformation of B-lymphocytes through a receptor in the tumor necrosis factor receptor family ${ }^{28}$. The B cell transformation is associated with activation and continuous proliferation. In immunocompetent individuals, the proliferation of B-lymphocytes is controlled by means of CD4 and CD8 cytotoxic T cells and natural killer (NK) cells. However, in patients who are immunosuppressed, the $\mathrm{T}$ cell function is inhibited and EBV induces uncontrolled B cell expansion. In initial stages, the proliferation is polyclonal. With mutation and selective growth, the lesions become oligoclonal and, later, monoclonal.

Patients who are EBV negative and receive grafts from EBV-positive individuals are at highest risk for developing PTLD $^{29}$. In this situation the EBV virus is transmitted from donor to recipient via the graft at the time of high immunosuppression for the recipient. For instance, in Cockfield's 1993 analysis it was found that the incidence of PTLD in patients who were EBV seronegative pretransplant was significantly higher than those who were seropositive $(23.1 \% \text { vs. } 0.7 \%)^{30}$. In another study from the Mayo Clinic of 381 adult nonrenal transplant recipients, the rate of developing PTLD was 24 times higher in EBV-negative than in EBV-positive recipients ${ }^{31}$.

PTLD that is not associated with EBV infection is less understood. Tumors not due to EBV also present a umber of different patterns. As reported in one French study, they develop much later (2324 vs. 546 days posttransplant) ${ }^{32}$.

\section{CLINICAL PRESENTATION AND DIAGNOSIS}

The clinical presentation of PTLD is highly variable. Some patients remain symptomless, in others, early symptoms can be nonspecific, such as fever, malaise and weight loss. Sometimes, the features resemble those of infectious mononucleosis, especially in children. Most lymphomas typically involve lymphnodes, however, extranodal involvement is also common ${ }^{33}$. As PTLD can assume a number of guises, a high degree of clinical vigilance is required if the diagnosis is not to be missed. In all transplant recipient with a fever of 3 days or more, clinical suspicion for PTLD increases ${ }^{34}$. A routine examination including laboratory tests and imaging studies, and lymph node extirpation is required to diagnose PTLD. Tissue biopsy is needed to determine PTLD histology. Immunohistology staining and serum PCR examination can be used to confirm the presence of EBV infection. EBV viral loads in the peripheral blood can be measured using EBV polymerase chain reaction $(\mathrm{PCR})^{35}$. In situ hybridization with the EBV-encoded RNA probe can detect EBV in tissue ${ }^{36}$. 


\section{INCIDENCE}

PTLD incidence varies according to the type of organ transplanted. An overall incidence of lymphoproliferative disorder approximately 30 to 50 times higher than in general population has been reported ${ }^{37,38}$. PTLD is most common in intestinal or multiorgan transplant recipients where the incidence ranges from 11 to 33 percent $^{16}$. In lung transplants it is 2 to 9 percent ${ }^{39-42,44}$ from 2 to 6 percent in heart transplants ${ }^{16,40,43,44}$ and from 1 to 3 percent in liver transplants ${ }^{39,45}$. The lowest PTLD incidence occurs in renal transplants with approximately one percent of the recipients being affected ${ }^{40,43}$. These findings suggest that PTLD incidence almost certainly reflects the need for more intensive immunosuppression in non-renal transplant recipients.

As shown in multiple studies, solid organ transplant patients at increased risk for PTLD are those treated with more intensive immunosuppression, especially those exposed to certain types of induction therapy ${ }^{30,43,44,46-48}$. In addition, the amount of lymphoid tissue that is transferred at organ transplantation increases the PTLD risk, as this transferred lymphoid tissue serves as reservoir for viruses such as EBV and Cytomegalovirus (CMV) ${ }^{49}$.

Age also carries a significant PTLD risk. Data from the IPITTR suggest that pediatric patients have a higher incidence of PTLD than do adults ( $53 \%$ vs. $15 \%$, respectively $)^{33}$. The rationale for this finding from a large number of studies is that, unlike adults, many pediatric patients have never been exposed to viruses such as EBV by the time of transplantation ${ }^{50}$.

\section{PREVENTION}

Reducing risk factors in organ transplant recipients seems to be the best strategy for preventing PTLD. The principal risk factors underlying the development of lymphoproliferative disorder posttransplant are the degree of overall immunusuppression and EBV serostatus of the recipient. An anti T cell immunosuppressive agent, a calcineurin inhibitor (cyclosporine or tacrolimus), an antiproliferative agent (mycophenolat mofetil, sirolimus or azathioprine), and corticosteroids are used to prevent organ rejection. Hence intense immunosuppression facilitates PTLD development. It is thus important to use the smallest combination and the lowest doses of required immunosuppressives ${ }^{51}$. Owing to the strong relationship between EBV and PTLD, screening for EBV infection and the use of antiviral agents may be beneficial ${ }^{52}$. The American Society of Transplantation recommends monthly EBV monitoring for the first posttransplant year in EBV-mismatched individuals ${ }^{53}$. The polymerase chain reaction (PCR) can detect changes in the EBV viral load over time, allowing for early detection of first-time EBV infections and EBV reactivation ${ }^{54}$. The effectiveness of both prophylactic use of antiviral agents and the early detection of primary EBV infection with PCR followed by antiviral therapy and immunosuppression reduction was evaluated in 40 children receiving a liver allograft. The result suggest that aggressive preemptive therapy and frequent monitoring for early EBV infection, which (when detected) is managed by intravenous ganciclovir and reduction of immunosuppression, may lower the incidence of PTLD ${ }^{55}$. In a retrospective multicenter case-control study of renal transplant recipients Funch et al reported that prophylactic antiviral therapy reduced the risk of PTLD. In this report of 100 biopsy-confirmed cases and 375 controls, the risk of PTLD during the first posttransplant year decreased by 38 percent for every 30 days of treatment with ganciclovir (OR of $0.62,95 \%$ CI $0.38-1.0)^{56}$. The specific antiviral agent to use is also a subject for discussion. The data suggest that ganciclovir may be more beneficial than acyclovir in reducing the PTLD risk. In the case-control study conducted by Funch et al. ( $n=100$ PTLD cases), for every 30 days of ganciclovir treatment, the risk of developing PTLD in the first year was decreased by 38 percent compared with only 17 percent risk reduction by using acyclovir ${ }^{57}$.

\section{TREATMENT}

In 1984 , Starzl et al. ${ }^{58}$ were the first to suggest reduction or withdrawal, of immunosuppression as a treatment option for PTLD. In immunocompetent individuals there are potent mechanisms of both humoral and cellular immunity (esp. CD4 and CD8 cytotoxic T cell and natural killer cells) which work well to prevent the outgrowth of EBV-infected lymphocytes. Thus reduction or withdrawal of immunosuppression serves to allow patients' natural immunity to recover and gain control over the proliferating EBV-infected cells again.

The majority of polyclonal lymphoproliferative disease lesions either resolve completely or improve significantly with only reductions of immunosuppression. EBV-related plasmocytomas may also disappear after reduction of immunosuppression $^{59}$. For example, Benkerrou et al. reported complete regression in 40 percent of patients after reduction or discontinuation of immunosuppressive thera$\mathrm{py}^{60}$. In Cohen's review, two thirds of transplant recipients with PTLD whose cases were managed with reduction of immunosuppression survived, compared with an overall survival rate of $31 \%$ (ref. ${ }^{61}$ ). Currently there is a general consensus that immunosuppression should be reduced or withdrawn in cases of PTLD in the first instance, however, no strict guidelines exist for this process. Hence the specific decision rests in the hands of the clinician who must consider the risk of allograft rejection after drug dose reduction or withdrawal. The aim is to achieve a balance - to improve immune function to gain remission from lymphoproliferation while at the same time preserving the allograft ${ }^{57}$.

Different immunosuppression reduction regiments have been tried based upon the severity of PTLD. Among those with only limited disease, one regiment is the reduction by at least 50 percent of cyclosporin (or tacrolimus) and prednisone, and discontinuation of azathioprine or mycophenolat mofetil. After two weeks, another 50 percent reduction of immunosuppression can be considered if necessary ${ }^{62}$. 
The results of these authors indicate that for localized PTLD both immunosuppression reduction alone and immunosuppression reduction combined with surgical excision are effective PTLD treatment. In a retrospective study of 42 adult transplant recipients with PTLD, cohorts were treated with either immunosuppression reduction alone $(n=30)$ or immunosuppression reduction plus surgical removal of all lesions $(n=12)$. Overall, 31 ( 74 percent) achieved complete remission. Among those treated with reduced immunosuppression alone, 63 percent had a complete or partial response rate within a median of 3,6 weeks after initiation. All 12 patients with localized PTLD who received surgery and reduced immunosuppression had complete response following surgery, with no relapses ${ }^{63}$.

A reduction in immunosuppressive therapy is not effective for central nervous system PTLD. CNS disease requires intrathecal therapy because intravenous chemotherapy and monoclonal antibodies do not cross the blood-brain barrier adequately ${ }^{64}$. Involved field radiation therapy may be beneficial for patients with CNS involvement ${ }^{65}$, and for those with localized disease ${ }^{66}$. Surgical management may also be useful, especially for the treatment of localized complications of the disease. In Cohen's review, survival rates of the order of 74 percent were noted for patients treated by surgical excision of the lesions, compared with an overall survival rate of 31 percent ${ }^{61}$.

T cell PTLD usually is not associated with EBV infection and does not respond to immunosuppression dose reduction ${ }^{67}$. Patients with more extensive disease but without critical illness should undergo a reduction in immunosuppression by either maintenance of steroid therapy only or decrease in calcineurine inhibitor dose by at least 50 percent and discontinuation of other immunosuppressants ${ }^{68}$. For such patients adjunctive therapy consisting of addition of rituximab or chemotherapy may be useful. Rituximab is a monoclonal anti-CD20 antibody, which has been used to treat B cell non-Hodgkin lymphoma. Its effectiveness in PTLD treatment has been demonstrated in multiple studies. For example Milpied et al. ${ }^{69}$ in France reported promising results with response rates of 65 percent in patients with PTLD treated with rituximab following solid organ transplantation. In Choquet's prospective study of 43 patients with previously untreated B cell PTLD not responding to immunosuppression reduction, rituximab was administered for four weeks at a dose of $375 \mathrm{mg} / \mathrm{m}^{2}$ per week. The overall response rate was 44 percent, while overall survival was 86 and 67 percent at 80 days and one year, respectively ${ }^{70}$.

Unfortunately, there are cases in which a patient does not respond to rituximab; in such a setting, chemotherapy is the next practicable option. One primary chemotherapy regiment used is CHOP (cyclophosphamide, doxoribicin, vincristine, prednisone) regiment. Its effectiveness has been shown in several studies with the remission rates of $69 \%$ achieved among patients with B cell tumors ${ }^{71,72}$. Similarly, Trappe et al. reported an overall response rate of $70 \%$ after $\mathrm{CHOP}$ administration among patient with refractory or relapsed disease after treatment with rituximab $^{73}$. In some reports, ProMACE-CytaBOM regi- ment was also effective for the posttransplant lymphoproliferation treatment ${ }^{74}$. The dose of doxorubicin in ProMACE-CytaBOM is half that used in CHOP, making ProMACE-CytaBOM less cardiotoxic and possibly a more attractive regiment. However, the complications associated with chemotherapy are not advantageous and therefore chemotherapy should be used as salvage therapy in patients who fail treatment with rituximab ${ }^{75}$. Patients who have diffuse PTLD involvement have a much lower response rate to treatment regiments. Additionally because these patients are critically ill, reduced immunosuppression, rituximab, or chemotherapy may lead to life-threatening complications. Currently, recommendations for these patients are limited and the outcome is dismal.

In addition to the agent previously discussed, there is some evidence that the use of antivirals, interferon-alfa or intravenous immunoglobulins may have benefits for patients with PTLD.

As with antiviral use in prevention, mainly ganciclovir and vangaciclovir are used in EBV-positive PTLD treatment ${ }^{76}$. Although there is widespread use of antivirals, no convincing rationale is provided for the efficacy of antiviral therapy in PTLD treatment. EBV PTLD arises from B cells transformed by EBV in which EBV survives as an episome outside the lymphocyte genome. In vivo, antivirals inhibit the replication of linear EBV DNA but are ineffective against episomal DNA which is the conformation of the EBV genome in latent B-lymphocyte, and so does not prevent their proliferation. Therefore antiviral agents are not recommended as the sole treatment of PTLD.

Interferon-alfa is a drug with antiviral and antiproliferative activity ${ }^{77}$ and it also inhibit T-helper cells, which release cytokines (IL-4, IL-6, IL-10) that promote B-cell proliferation $^{78}$. However, its use for PTLD treatment also remains controversial. To date no prospective clinical trials have been conducted and most of the reports of its success are anecdotal. The largest series described 14 solid organ transplant recipients with systemic PTLD who were treated with interferon alpha (3 million units/ $\mathrm{m}^{2}$ per day for at least three weeks), combined with immunosuppression reduction. Eight patients achieved total disease regression. The therapy was continued for 6 to 9 months. None of patients had a relapse with the same neoplastic clone but 2 developed a new neoplastic clone ${ }^{77}$. Intravenous immunoglobulin (IGIV, IVIG) has been successfully used as adjunctive therapy in the management of PTLD in combination with other modalities, mainly with interferon-alpha ${ }^{79}$.

New immune-based strategy for PTLD treatment is based on the fact that EBV specific cytotoxic T lymphocytes have the ability to recognize and destroy EBV-infected B cells. Since the technology to stimulate autologous EBV-specific cytotoxic T lymphocytes (CTL) ex vivo is now available, treatment of PTLD that is of recipient origin includes transfer of ex vivo generated recipient's EBV-specific cytotoxic T lymphocytes. As shown in one survey of clinical results, adoptive therapy with EBV-specific CTL is safe, well tolerated and particularly effective $^{80}$. 
Another potential therapeutic strategy could be to try to induce lytic EBV infection in the tumor cells. This could be done by targeting genes that switch the EBVinfected B cells from the latent to the lytic cycle ${ }^{81}$.

\section{CONCLUSIONS}

Transplantation and the accompanying drug-induced immunosuppression put patients at risk for potentially fatal infection and malignancy. As the number of transplants increase and the life expectancy of transplant recipients improves, increased rates of PTLD and other malignancies are anticipated. Among those who are in a high risk of developing PTLD are EBV-seronegative patients, nonrenal transplant recipients, patients with intense immunosuppression management, and children. To prevent PTLD, minimizing the immunosuppression burden, regular PCR EBV screening and use of antiviral agents appear to be useful strategies. PTLD treatment includes lowering of immunosuppression, antiviral therapy, surgical support, chemotherapy, radiation and cellular therapy. However, the optimal therapy strategy still remains to be determined. There is still a great necessity for prospective randomized clinical trials to test the effectiveness of current strategies. Productive areas of investigation include: identifying patients who will benefit from reduction of immunosuppression only; improving methods for predicting those at highest risk of PTLD; developing safe and effective pre-emptive therapies; and developing more effective, less toxic therapies for resistant or aggressive disease.

\section{REFERENCES}

1. Swinnen LJ. Treatment of organ transplant-related lymphoma. Hematol Oncol Clin North Am 1997;11:963-973.

2. Boubenider S, Hiesse C, Goupy C, Kriaa F, Marchand S, Charpentier B. Incidence and consequences of posttransplant lymphoproliferative disorders. J Nephrol 1997;10:136-145.

3. Nalesnik MA. Clinicopathologic characteristics of posttransplant lymphoproliferative disorders - Recent results. Cancer Res 2002;159:9-18.

4. Loren AW, Porter DL, Stadtmauer EA, Tsai DE. Posttransplant lymphoproliferative disorder: a review. Bone Marrow Transplant 2003;31:145-155.

5. Herzig KA, Juffs HG, Norris D, Brown AM, Gill D, Hawley CM et al. A single centre experience of post-renal transplant lymphoproliferative disorder. Transpl Int 2003;16:529-536.

6. Shroff R, Rees L. The posttransplant lymphoproliferative disorder: a literature review. Pediatr Nephrol 2004;19:365-368.

7. Leblond, V, Sutton, L, Dorent, R, Davi F, Bitker MO, Gabarre J et al. Lymphoproliferative disorders after organ transplantation: a report of 24 cases observe $d$ in a single center. J Clin Oncol 1995;13:961-967.

8. Hanson MN, Morrison VA, Peterson BA, Stieglbauer KT, Kubic VL, McCormick SR et al. Posttransplant T-cell lymphoproliferative disorders - an aggressive, late complication of solid-organ transplantation. Blood 1996;88:3626-33.

9. Draoua HY, Tsao L, Mancini DM, Addonizio LJ, Bhagat G, Alobeid B. T-cell post-transplantation lymphoproliferative disorders after cardiac transplantation: a single institutional experience. $\mathrm{Br} \mathrm{J}$ Haematol 2004;127:429-54
10. Ravat FE, Spittle MF, Russell-Jones R. Primary cutaneous T-cell lymphoma occurring after organ transplantation. J Am Acad Dermatol 2006;54:668-72.

11. Rajakariar R, Bhattacharyya M, Norton A, Sheaff M, Cavenagh J, Raftery MJ et al. Post transplant T-cell lymphoma: a case series of four patients from a single unit and review of the literature. Am J Transplant 2004;4:1534-39.

12. Jamali FR, Otrock ZK, Soweid AM, Al-Awar GN, Mahfouz RA, Haidar GR et al. An overview of the pathogenesis and natural history of post-transplant T-cell lymphoma. Leuk Lymphoma 2007;48:1780-84.

13. Kotton CN, Fishman JA. Viral infection in the renal transplant recipient. J Am Soc Nephrol 2005;16:1758-63.

14. Petit B, Le Meur Y, Jaccard A. Paraf F, Robert CL, Bordessoule $\mathrm{D}$ et al. Influence of host-recipient origin on clinical aspects of posttransplantation lymphoproliferative disorders in kidney transplantation. Transplantation 2002;73:265-70.

15. Dolcetti R. B lymphocytes and Epstein-Barr virus: The lesson of post-transplant lymphoproliferative disorders. Autoimmun Rev 2007;7:96-101.

16. Cockfield SM. Identifying the patients at risk for posttransplant lymphoproliferative disorder. Transplant Infect Dis 2001;3:70-80.

17. Lim WH, Russ GR, Coates PT. Review of Epstein-Barr virus and post-transplant lymphoproliferative disorder post-solid organ transplantation. Nephrology 2006;11:355-66.

18. Nalesnik MA, Makowka L, Starzl TE. The diagnosis and treatment of posttransplant lymphoproliferative disorders. Curr Probl Surg 1988;25:367-372.

19. Caillard S, Agodoa LY, Bohen EM, Abbott KC. Myeloma, Hodgkin disease, and lymphoid leukemia after renal transplantation: characteristics, risk factors and prognosis. Transplantation 2006;81:88893.

20. Hanto DW, Frizzera G, Purtilo DT, Sakamoto K, Sullivan JL, Saemundsen A et al. Clinical spectrum of lymphoproliferative disorders in renal transplant recipients and evidence for the role of Epstein-Barr virus. Cancer Res 1981;41:4253-4261.

21. Frizzera G, Hanto DW, Gajl-Peczalska KJ, Rosai J, McKenna RW, Sibley RK. Polymorphic Diffuse B-Cell Hyperplasias and Lymphomas in Renal Transplant Recipients. Cancer Res 1981;41:4262-79.

22. Nalesnik MA, Jaffe R, Starzl TE, Demetris AJ, Porter K, Burnham JA. The Pathology of Posttransplant Lymphoproliferative Disorders Occurring in the Setting of Cyclosporine A - Prednisone Immunosuppression. Am J Pathol 1988;133:173-192.

23. Locker J, Nalesnik M. Molecular genetic analysis of lymphoid tumors arising after organ transplantation. Am J Pathol 1989;135: 977-987.

24. Knowles DM, Cesarman E, Chadburn A, Frizzera G, Chen J, Rose EA et al. Correlative morphologic and molecular analysis demonstrates three distinct categories of posttransplant lymphoproliferative disorders. Blood 1995;85:552-565.

25. Harris NL, Ferry JA, Swerlow SH. Posttransplant lymphoproliferative disorders: Summary of Society for Hematopathology Workshop. Semin Diagn Pathol 1997;14:8-14.

26. Harris NL, Swerlow SH, Frizzera G, Knowles DM. Posttransplant lymphoproliferative disoders. In: Jaffe ES, Harris NL, Stein H, Vardiman JW: World Health Organization Classification of Tumors. Pathology and Genetics of Tumors of Haematopoietic and Lymphoid Tissue. Lyon: IARC Press; 2001.p.264-269.

27. Cohen JI. Eppstein-Barr virus infection. N Engl J Med 2000;343:481-92.

28. Mosialos G, Birkenbach M, Yalamanchili R, VanArsdale T, Ware $\mathrm{C}$, Kieff E. The Epstein-Barr virus transforming protein LMP1 engages signaling proteins for the tumor necrosis factor receptor family. Cell 1995;80:389-399.

29. Knight JS, Tsodikov A, Cibrik DM, Ross CW, Kaminski MS, Blayney MW. Lymphoma After Solid Organ Transplantation: Risk, Response to Therapy, and Survival at a Transplantation Center. J Clin Oncol 2009;27:3354-62.

30. Cockfield SM, Preiksaitis JK, Jewell LD, Parfrey NA. Posttransplant Lymphoproliferative Disorder in Renal Allograft Recipients. 
Clinical Experience and Risk Factor Analysis in a Single Center. Transplantation.1993;56:88-96.

31. Walker RC, Marshall WF, Strickler JG, Wiesner RH, Velosa JA, Habermann TM et al. Pretransplantation assessment of the risk of lymphoproliferative disorder. Clin Infect Dis 1995;20:1346-53.

32. Leblond V, Davi F, Charlotte F, Dorent R, Bitker MO, Sutton L et al. Posttransplant lymphoproliferative disorders not associated with Epstein-Barr virus: A distinct entity? J Clin Oncol 1998;16:205259.

33. Penn I. Postransplant Malignancy: the Role of Immunosuppression. Drug Saf 2000;23:101-13.

34. Green M. Management of Epstein-Barr Virus-induced Posttransplant Lymphoproliferative Disease in Recipient of Solid Organ Transplantation. AM J Transplant 2001;1:103-8.

35. Gärtner BC, Fischinger J, Schäfer H, Einsele H, Roemer K, MüllerLantzsch N. Epstein-Barr virus load monitoring: its role in the prevention and management of post-transplant lymphoproliferative disease. Recent Results. Cancer Res 2002;159:49-54.

36. American Society of Transplantation. Epstein-Barr Virus and Lymphoproliferative Disorder after Transplantation. Guidelines for the Prevention and Management of Infectious Complications of Solid Organ Transplantation. Am J Transplant 2004;4(suppl 10): 59-65.

37. Andreone P, Gramenz A, Lorenzini S, Biselli M, Cursaro C, Pileri S, Bernardi M. Posttransplantation lymphoproliferative disorders. Arch Intern Med 2003;163:1997-2004.

38. Caillard S, Lelong C, Pessione F, Moulin, B. Post-transplant lymphoproliferative disorders occurring after renal transplantation in adults: report of 230 cases from the French registry. Am J Transplant 2006;6:2735-39.

39. Walker RC, Paya CV, Marshall WF, Strickler JG, Wiesner RH, Velosa JA et al. Pretransplantation seronegative Epstein-Barr virus status is the primary risk factor for posttransplantation lymphoproliferative disorder in adult heart, lung, and other solid organ transplantations. J Heart Lung Transplant 1995;14:214-21.

40. Armitage JM, Kormos RL, Stuart RS, Fricker FJ, Griffith BP, Nalesnik $\mathrm{M}$ et al. Posttransplant lymphoproliferative disease in thoracic organ transplant patients: Ten years of cyclosporine-based immunosuppression. J Heart Lung Transplant 1991;10:877-86.

41. Aris RM, Maia DM, Neuringer IP, Gott K, Kiley S, Gertis K, Handy J. Post-transplantation lymphoproliferative disorder in the Epstein-Barr virus-naive lung transplant recipient. Am J Respir Crit Care Med 1996;154:1712-17.

42. Levine SM, Angel L, Anzueto A, Susanto I, Peters JI, Sako EY, Bryan CL. A low incidence of posttransplant lymphoproliferative disorder in 109 lung transplant recipients. Chest 1999;116:1273-77.

43. Opelz G, Henderson R Incidence of non-Hodgkin lymphoma in kidney and heart transplant recipients.Lancet 1993;342:1514-16.

44. Swinnen LJ, Costanza-Nordin MR, Fisher SG, O'Sullivan EJ, Johnson MR, Heroux AL et al. Increased incidence of lymphoproliferative disorders after immunosuppression with the monoclonal antibody OKT3 in cardiac transplant recipients. N Engl J Med 1990;323:1723-28.

45. Penn I. Posttransplantation de novo tumors in liver allograft recipients. Liver Transpl Surg 1996;2:52-57.

46. Bustami RT, Ojo AO, Wolfe RA, Merion RM, Bennett WM, McDiarmid SV et al. Immunosuppression and the risk of posttransplant malignancy among cadaveric first kidney transplant recipients. Am J Transplant 2004;4:87-93.

47. Opelz G, Dohler B. Lymphomas after solid organ transplantation: a collaborative transplant study report. Am J Transplant 2004;4:22225 .

48. Opelz G, Naujokat C, Daniel V, Terness P, Döhler B. Disassociation between risk of graft loss and risk of non-Hodgkin lymphoma with induction agents in renal transplant recipients. Transplantation 2006;81:1227-33.

49. Everly MJ, Bloom RD, Tsai DE, Trofe J. Posttransplant lymphoproliferative disorder. Ann Pharmacother 2007;41:1850-58.

50. Shapiro R, Nalesnik MA, McCauley J, Fedorek S, Jordan ML, Scantlebury VP. Posttransplant lymphoproliferative disorders in adult and pediatric renal transplant patients recieving tacrolimus based immunosuppression. Transplantation 1999;68:1851-54.
51. Peddi VR, Bryant M, Roy-Chaudhury P, Woodle ES, First MR. Safety, efficacy, cost analysis of thymoglobulin therapy with intermittent dosing based on CD3+ lymphocytes counts in kidney and kidney-pancreastransplant recipients. Transplantation 2002;73:1514-8.

52. Muti G, Klersy C, Baldanti F. Granata S, Oreste P, Pezzetti L et al. Epstein-Barr virus (EBV) load and interleukin-10 in EBV-positive and EBV-negative post-transplant lymphoproliferative disorders. $\mathrm{Br}$ J Haematol 2003;122:927-33.

53. Humar A, Micheals M. American Society of Transplantation recommendation for screening, monitoring and reporting of infections complications in immunosuppression trial in recipients of organ transplantation. Am J Transplant 2006;6:262-74.

54. Tsai DE, Nearey M, Hardy CL, Tomaszewski JE, Kotloff RM, Grossman RA et al. Use of EBV PCR for the diagnosis and monitoring of post-transplant lymphoproliferative disorder on adult solid organ transplant patients. Am J Transplant 2002;2:946-54.

55. McDiarmid SV, Jordan S, Kim GS, Toyoda M, Goss JA, Vargas JH et al. Prevention and preemptive therapy of posttransplant lymphoproliferative disease in pediatric liver recipients. Transplantation 1998;66:1604-11.

56. Funch DP, Walker AM, Schneider G, Ziyadeh NJ, Pescovitz MD. Ganciclovir and acyclovir reduce the risk of posttransplant lymphoproliferative disorder in renal transplant recipients. Am J Transplant 2005;5:2894-2900.

57. Funch DP, Brady J, Ko HH, Dreyer NA, Walker AM. Methods and objectives of large US multicenter study of posttransplant lymfoproliferative disorder in renal transplant recipients. Recent results. Cancer Res. 2002;159:81-8.

58. Starzl TE, Nalesnik ME, Porter KA, Ho M, Iwatsuki S, Griffith BP et al. Revesibility of lymphomas and lymphoproliferative lesions developing under cyclosporine-steroid therapy. Lancet 1984;1:583-87.

59. Rees L, Thomas A, Amlot PL. Disappearance of an Epstein-Barr virus-positive post-transplant plasmocytoma with reduction of immunosuppression. Lancet 1998;352:789.

60. Benkerrou M, Jais JP, Leblond V, Durandy A, Sutton L, Bordigoni $\mathrm{P}$ et al. Anti-B-cell monoclonal antibody treatment of severe posttransplant B-lymphoproliferative disorder: prognostic factors and long-term outcome. Blood 1998;92:3137-47.

61. Cohen JI. Epstein-Barr virus Lymphoproliferative Disorder Associated with Acquired Immunodeficiency. Medicine 1991;70:137-60.

62. Paya CV, Fung JJ, Nalesnik MA, Kieff E, Green M, Gores G et al. Epstein-Barr virus-induced posttransplant lymphoproliferative disorders. ASTS/ASTP EBV-PTLD Task Force and Mayo Clinic Organized International Concensus Development Meeting. Transplantation 1999;68:1517-25.

63. Tsai DE, Hardy CL, Tomaszewski JE, Kotloff RM, Oltoff KM, Somer BG et al. Reduction in immunosuppression as initial therapy for posttransplant lymphoproliferative disorder: analysis of prognostic variables and long-term follow up of 42 adult patients. Transplantation 2001;71:1076-88.

64. Van de Glind G, de Graaf S, Klein C, Cornelissen M, Maecker B, Loeffen J. Intrathecal Rituximab Treatment for Pediatric Posttransplant Lymphoproliferative Disorder of The Central Nervous System. Pediatr Blood Cancer 2008;50:886-88.

65. Snanoudj R, Durrbach A, Leblond V, Caillard S, Hurault De Ligny B, Noel C. Primary brain lymphomas after kidney Transplantation: Presentation and outcome. Transplantation 2003;76:930-37.

66. Koffman BH, Kennedy AS, Heyman M, Colonna J, Howell C. Use of Radiation Therapy in Posttransplant Lymphoproliferative Disorder (PTLD) after Live Transplantation. Int J Cancer 2000;90:104-9.

67. Hanson MN, Morrison VA, Peterson BA, Stieglbauer KT, Kubic VL, McCormick SR et al. Posttransplant T-cell Lymphoproliferative Disorder - An Aggressive, Late Complication of Solid-Organ Transplantation Blood 1996;88:3626-33.

68. EBPG Expert Group on Renal Transplantation. European best practice guideline for renal transplantation. Section IV: long term management of the transplant recipient.IV.6.1. Cancer risk after renal transplantation. Posttransplant lymphoproliferative disease 
(PTLD): prevention and treatment. Nephrol Dial Transplant 2002;17:31-3.

69. Milpied N, Vasseur B, Parquet N, Garnier JL, Antoine C, Quartier $\mathrm{P}$ et al. Humanized anti-CD20 monoclonal antibody (Rituximab) in post transplant B-lymphoproliferative disorder: a retrospective analysis on 32 patients. Ann Oncol. 2000;11:113-6.

70. Choquet S, Leblond V, Herbrecht R, Socié G, Stoppa AM, Vandenberghe P. Efficacy and safety of rituximab in B-cell posttransplant lymphoproliferative disorders: result of prospective multicenter phase 2 study. Blood 2006;107:3053-7.

71. Balfour IC, Wall d, Luisiri A, Sotelo C, Gross TG. Cyclophosphamide/prednisone for combination immunosuppression and therapy of lymphoproliferative disease. J Heart Lung Transplant 1999;18:492-5.

72. Orjuela M, Gross TG, Cheung Y, Alobeid B, Morris E, Cairo MS. A pilot study of chemoimmunotherapy (cyclophosphamide, prednisone and rituximab) in patient with posttransplant lymphoproliferative disorders following solid organ transplantation. Clin Cancer Res 2003;9:3945S-52S.

73. Trappe R, Riess H, Babel N, Hummel M, Lehmkuhl H, Jonas S et al. Salvage Chemotherapy for Refractory and Relapsed Posttransplant Lymphoproliferative Disorder (PTLD) After Treatment With Single-Agent Rituximab. Transplantation 2007;83: 912-18.

74. Swinnen LJ, Mullen GM, Carr TJ, Constanzo MR, Fischer RI Aggressive Treatment for Postcardiac Transplant Lymphoproliferation. Blood 1995;86:3333-40.
75. Elstrom RL, Andreadis C, Aqiu NA, Ahya VN, Bloom RD, Brozena SC et al. Treatment of PTLD with rituximab or chemotherapy. Am J Transplant 2006;6:596-76.

76. Hierro L, Díez-Dorado R, Díaz C, De la Vega A, Frauca E et al. Efficacy and safety of valganciclovir in liver-transplanted children infected with Epstein-Barr virus, Liver Transplant 2008;14:118593.

77. Davis CL, Wood BL, Sabath DE, Joseph JS, Stehman-Breen C, Broudy VC et al. Interferon -Alpha Treatment of Posttransplant Lymphoproliferative Disorder in Recipient of Solid Organ Transplants. Transplantation 1998;66:1770-79.

78. Crossey AR, Dickenson AM, Proctor SJ, Calvert JE. Effects of Interferon - Alpha Therapy on Immune Parameters in Immune thrombocytopenic Purpura. Autoimmunity 1996;24:80-100.

79. Cantarovich M, Barkun JS, Forbes RD. Successful Treatment of Posttransplant Lymphoproliferative Disorder with Interferon-Alpha and Intravenous Immunoglobulin. Clin Transplant 1998;12:10913 .

80. Merlo A, Turrini R, Dolcetti R, Zanovello P, Amadori A. Adoptive Cell Therapy Against EBV-related malignancies: A Survey of Clinical Results. Expert Opin Biol Ther 2008;8:1265-94.

81. Cohen JI, Bollard CM, Khanna R, Pittaluga S. Current Understanding of the Role of Epstein-Barr Virus in Lymphomagenesis and Therapeutic Approaches to EBV-associated Lymphomas. Leuk Lymphoma 2008;49:27-34. 
